Supplement of Atmos. Chem. Phys., 16, 5721-5743, 2016

http://www.atmos-chem-phys.net/16/5721/2016/

doi:10.5194/acp-16-5721-2016-supplement

(C) Author(s) 2016. CC Attribution 3.0 License.

(c) (i)

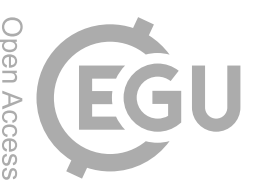

Supplement of

\title{
Ozone variability in the troposphere and the stratosphere from the first 6 years of IASI observations (2008-2013)
}

Catherine Wespes et al.

Correspondence to: Catherine Wespes (cwespes@ulb.ac.be)

The copyright of individual parts of the supplement might differ from the CC-BY 3.0 licence. 


\section{Contents of this file}

2 Sections 1 to 4 - Table S1 - Figures S1 to S6

3

$4 \quad$ Introduction

5 This supporting information provides, in Table S1, a tabulated summary of the variables that are

6 kept in the statistical model at the 95\% level at the end of the iterative backward selection for

7 each $20^{\circ}$ latitude bands and for each partial column analyzed in the manuscript.

8

9 This supplement also gives details on model-measurement comparisons in subsections below.

10 First, we evaluate the variations in $\mathrm{O}_{3}$ simulated with MOZART-4 (Emmons et al., 2010a)

11 against IASI by using the regression model described in the manuscript (Section 3). This

12 statistical model is used as a tool for understanding possible biases between MOZART-4 and

13 IASI. Then, the stratospheric influence as seen by IASI in the $\mathrm{O}_{3}$ tropospheric column (Section 4

14 of the manuscript) is estimated.

\section{S.1 MOZART-4 simulation set up}

17 The simulations are performed over the IASI period after a 6-month spin-up and they are driven 18 by offline meteorological fields from the NASA Global Modeling and Assimilation Office (GMAO) Goddard Earth Observing System (GEOS-5) assimilation products 20 (http://gmao.gsfc.nasa.gov/products/). MOZART-4 was run with a horizontal resolution of $212.5^{\circ} \times 1.9^{\circ}$, with 56 levels in the vertical and with its standard chemical mechanism. In the 22 stratosphere, MOZART-4 does not have a detailed chemistry and $\mathrm{O}_{3}$ is constrained to 23 observations from satellite and ozonesondes (Horowitz et al., 2003). The emissions inventory used here is the same as in Wespes et al. (2012) and in Duflot et al. (2015). The anthropogenic emissions are from the inventory provided by D. Streets (Argonne National Lab) and University 26 of Iowa for ARCTAS (http://bio.cgrer.uiowa.edu/arctas/emission.html; 27 http://bio.cgrer.uiowa.edu/arctas/arctas/07222009/). It is a composite dataset of regional emissions representative of emissions for 2008: it is built upon the INTEX-B Asia inventory

29 (Zhang et al.,2009) with the US NEI (National Emission Inventory) 2002 and CAC 2005 for 30 North America and the EMEP (European Monitoring and Evaluation Programme) 2006 for 
Europe inventory to make up NH emissions (see http://bio.cgrer.uiowa.edu/arctas/emission.html and Emmons et al. 2015 for an evaluation of the inventory with several models in the frame of the POLARCAT Model Intercomparison Program (POLMIP)). Emissions from EDGAR (Emissions Database for Global Atmospheric Research) were used for missing regions and species. The anthropogenic emissions are constant over years with no monthly variations. Daily biomass burning emissions are taken from the global Fire INventory from NCAR (FINN, Wiedinmyer et al., 2011). They vary with year. The oceanic emissions are taken from the POET emissions dataset (Granier et al., 2005) and the biogenic emissions from MEGANv2 (Model of Emissions of Gases and Aerosols from Nature) inventory (Guenther et al., 2006). Details on chemical mechanisms, parameterizations and emission sources can be found in Emmons et al. observations in space and time. (2010a; 2012; 2015). MOZART-4 simulations of numerous species (including $\mathrm{O}_{3}$ and related tracers) have been previously compared to ozonesondes, aircrafts and satellite observations and used to track the intercontinental transport of pollution (e.g., Emmons et al., 2010b; 2015; Pfister et al., 2006; 2008; Wespes et al., 2012). Results have shown that MOZART-4 is slightly biased low over the troposphere (around 5-15\%), but that it reproduces generally well the variability of

$$
\text { observations in space and time. }
$$

\section{$\mathrm{S}_{2} \mathrm{O}_{3}$ time series from MOZART-4 vs IASI}

In Fig. S2, the seasonal cycles of ozone columns from MOZART-4 fitted regression model are compared against the IASI fitted columns by taking into account its associated averaging kernels (see Section 2 of the manuscript) following the formalism of Rodgers (2000):

$X_{\text {Model_Smoothed }}=X a+\mathbf{A}\left(X_{\text {Model }}-X a\right)$

where $X_{\text {Model }}$ represents the $\mathrm{O}_{3}$ profile modeled by MOZART-4 which is first vertically interpolated to the pressure levels of the a priori profiles $(\mathrm{Xa})$ used in the FORLI-O $\mathrm{O}_{3}$ retrieval algorithm. In the stratosphere (UST and MLST), despite the non-explicit representation of the chemistry and the coarse vertical resolution in this layer, MOZART-4 reproduces the observations in terms of ozone concentrations, amplitude of the seasonal cycle and timing of the maximum. Differences between the fitted cycles associated with the simulations and the observations are lower than $10 \%$, except over the Southern polar region where they reach $30 \%$. In the UTLS region, while the amplitudes of the seasonal cycles and the timing of the maxima 
are well captured in the model, we observe a systematic bias with an underestimation of $\mathrm{O}_{3}$ concentrations in the model of around $30 \%$ over the high latitudes (north of $50^{\circ} \mathrm{N}$ and south of $\left.50^{\circ} \mathrm{S}\right)$, possibly resulting from a misrepresentation of the STE processes.

In the troposphere, on the contrary to the upper layers, the model shows for each 20-degree latitude band an overestimation of the ozone concentrations, particularly in tropical and extratropical regions (reaching $25 \%$ in the equatorial belt), as well as a mismatch in the timing of the maximum which occurs one to two months before the observed spring peak, especially in the N.H. The shift of the maximum from high to mid-latitudes observed by IASI in the N.H. (see Section 4.1 and Fig. 7 of the manuscript) is not reproduced by MOZART-4 which shows a latitudinal independent maximum in April. This is likely explained by the constant in time anthropogenic emissions used in MOZART-4. This finding gives further confidence to the ability of IASI to detect anthropogenic production of $\mathrm{O}_{3}$. The mismatch in the timing of the maximum in the troposphere is characterized by different regression coefficients for the annual term from MOZART-4 and IASI. The annual component (Constant scaled $a_{1}+b_{1}$ ) decreases from Northern latitudes (from 5\% to 10\%) to high Southern latitudes (from -30\% to 0\%) with negative amplitudes south of $10^{\circ} \mathrm{N}$ and a maximum positive amplitude at $20^{\circ} \mathrm{N}(10 \%)$ for MOZART-4, while IASI shows negative values both south of the equator $(-20-0 \%)$ and north of $30^{\circ} \mathrm{N}(-10-$ $0 \%$ ) and a similar maximum at $20^{\circ} \mathrm{N}$ (see Fig.8b of the manuscript). Note that this misrepresentation of MOZART-4 in the UTLS and in the troposphere is unlikely due to errors in climatology values used in the stratosphere since the concentrations and the timing of the maximum are well reproduced in that layer.

To better evaluate the sources of the discrepancies between model and measurement, we compare the constant terms from MOZART-4 time series with IASI (Fig.S3, also Fig.8a of the manuscript) using the regression procedure (Section 3 of the manuscript). The comparison indicates that MOZART-4 has a good climatology in the US and MLS (differences < 10\%). The biases of MOZART-4 in the UTLS and in the troposphere reported above are highlighted in the fitted constant with, in UTLS, underestimations of $\sim 35 \%$ and $\sim 15 \%$ over the high Southern and Northern latitudes, respectively, and, in the troposphere, an overestimation reaching $\sim 25 \%$ in the 
91 tropics. The latter could possibly point out issues with horizontal transport in the model or 92 overestimated ozone production efficiency at these latitudes.

\section{S.3 Stratospheric influences as seen by IASI}

95 After verifying above the agreement between the $\mathrm{O}_{3}$ time series from IASI and from MOZART4 , we can investigate to what extent the stratosphere could influence the $\mathrm{O}_{3}$ variations seen by IASI in the troposphere. To this end, we focus hereafter on variations in the MLT, using a “tagging" method to track all tropospheric odd nitrogen sources (the "tagged" nitrogen species) producing ozone $\left(\mathrm{O}_{3}{ }^{\text {tagged_NOx }}\right)$ through the tropospheric photochemical reactions in MOZART-4 (see Emmons et al. (2012) for detailed information on the "tagging" approach and on the photolysis and kinetic reactions for the tagged species). This method allows the quantification of the portion of the stratosphere to the tropospheric $\mathrm{O}_{3}$. Since the method is fully linear, this contribution is simply calculated as the difference between the total simulated $\mathrm{O}_{3}$ and the $\mathrm{O}_{3}{ }^{\text {tagged_NOx }}$ (Emmons et al., 2012; Wespes et al., 2012). Fig.S4 (a) presents, for each 20-degree latitude band, the averaged seasonal cycles in the MLT for total $\mathrm{O}_{3}$ (solid line) and $\mathrm{O}_{3}{ }^{\text {tagged_NOx }}$ (dashed lines) from fitted MOZART-4 time series. The difference between total $\mathrm{O}_{3}$ and $\mathrm{O}_{3}{ }^{\text {tagged_NOx }}$ is expressed in Fig.S4 (b) as a percentage of the total $\mathrm{O}_{3}$. It represents the natural 108 stratospheric influence into the MLT columns as modeled by MOZART-4 and it ranges between 109 $\sim 20 \%$ to $45 \%$ with, as expected, the largest contribution above the winter southern latitudes. Fig. S5 is the same as Fig. S4 but the model time series account for the IASI vertical sensitivity by applying the averaging kernels (A) of each specific IASI observation to the corresponding gridded MOZART-4 profile (see Eq. S1), similarly to Wespes et al. (2012). Eq. S1 can be

113 expressed as :

$X_{\text {Model_Smoothed }}=\left[\mathbf{A} X_{O 3 \_t a g g e d \_N O x}\right]+\left[\mathbf{A}\left(X_{\text {Model }}-X_{\text {O3_tagged_NOx }}\right)\right]+\left[X_{a}-\mathbf{A}\left(X_{a}\right)\right]$ where the first two terms represent the contributions from all the tropospheric odd nitrogen sources and from the stratosphere smoothed by the averaging kernels, respectively. The third component represents the contribution from the a priori to the columns due to the limited vertical sensitivity of the IASI instrument. These terms are represented in Fig. S5 (a) and (b) for the MLT. The second term which is illustrated as a percentage of the total $\mathrm{O}_{3}$ in Fig. S5 (b) (solid lines), simulates the stratospheric part as seen by IASI in the troposphere. This IASI stratospheric 
121 contribution, which is amplified by the limited vertical sensitivity of the instrument in the MLT 122 when compared with the MOZART-4 stratospheric influence (Fig. S4 (b)), ranges between 30 and 65\% depending on latitude and season. The largest contributions are calculated for the highest latitudes in winter-spring and they are attributed to both descent of stratospheric air mass into the polar vortex and to less IASI sensitivity over the poles. The low contribution above the South polar region ( $25 \%)$ is explained by a loss of IASI sensitivity which translates to a large a priori contribution (40\%). The smallest stratospheric contributions are calculated in the low latitude bands. The difference between the stratospheric contributions simulated by MOZART-4 (Fig. S4 (b)) and those as seen by IASI (Fig. S5 (b)) is the stratospheric portion due to the IASI limited sensitivity and it reflects the smoothing error from the IASI measurements. It ranges between 10\%-20\% (except for the polar bands). This suggests that the limited vertical sensitivity of IASI, which artificially mixes stratospheric and tropospheric air masses, contributes to a lesser extent to the IASI MLT than the stratosphere-troposphere exchanges. The smoothing error translates also to an a priori contribution (dashed lines in Fig. S5 (b)) which, as expected from the analysis of the IASI vertical sensitivity (see Section 2 of the manuscript), is anti-correlated with the stratospheric contribution to some extent. It ranges between $\sim 5 \%$ and $\sim 20 \%$. These results suggest that the variability of tropospheric ozone measured by IASI (Section 4.3.2 of the manuscript) is partly masked by the a priori and the stratospheric contributions.

The total portion of the natural variability (from both the troposphere and the stratosphere) into the MLT $\mathrm{O}_{3}$ measured by IASI can be estimated by subtracting from the IASI $\mathrm{O}_{3}$ time series the a priori contribution and the stratospheric one due to the IASI limited sensitivity. This is illustrated in Fig.S6 (a). This natural contribution is larger than 50\% of the IASI MLT O 3 column everywhere. Interestingly, the $30^{\circ} \mathrm{N}-50^{\circ} \mathrm{N}$ band shows the highest detectable natural portion ( $\sim 80-85 \%)$ in the MLT columns, from which $\sim 20-35 \%$ originates from the stratosphere (Fig. S4 (b)), and 50-60\% from the troposphere (Fig.S6 (b)). It is also worth to note that the positive bias of MOZART-4 vs. IASI in the MLT (see Section S2) should not affect the calculated tropospheric contribution in the IASI MLT columns and that the stratospheric contribution for the $30^{\circ} \mathrm{N}-50^{\circ} \mathrm{N}$ band should be well estimated from MOZART-4 since the model matches very well the IASI observations in the upper layers for this band (Fig. S2 and S3). 
152 To further characterize the stratospheric influence, the constant factors associated with the $\mathrm{O}_{3}{ }^{\text {tagged_NOx }}$ fitting time series in the troposphere are superimposed in Fig.S3 (dashed grey line).

154 They represent between 40 and $60 \%$ of the constant factors derived from the total $\mathrm{O}_{3}$ fitting. The 155 north-south gradient for the $\mathrm{O}_{3}{ }^{\text {tagged_NOx }}$ is smaller than for the total $\mathrm{O}_{3}$, with maximum over the 156 low latitudes of the N.H. while, for the total $\mathrm{O}_{3}$, maximum is found over the high latitudes. From 157 Fig.S4 (a), we see in the N.H. that the differences between the variability of total $\mathrm{O}_{3}$ and that of $158 \mathrm{O}_{3}{ }^{\text {tagged_NOx }}$ mainly result from the timing of the maximum with a shift of 2-3 months (maximum 159 in spring for the total $\mathrm{O}_{3} v s$ maximum in summer for the $\mathrm{O}_{3}{ }^{\text {tagged_NOx }}$ ). That shift is characterized 160 by a positive annual component (constant scaled $a 1+b 1)$ for the total $\mathrm{O}_{3}(\sim 10 \%)$ and a negative 161 one for the $\mathrm{O}_{3}{ }^{\text {tagged_NOx }}(\sim-20 \%)$. In the S.H., we observe a same timing of the maximum 162 between the two runs.

\section{Conclusions}

165 Two important results can be derived from MOZART-4 vs IASI time series:

166 1- By comparing the fitted $\mathrm{O}_{3}$ variations and regression coefficients using the same regression 167 model, systematic biases are found in the troposphere and can be attributed to specific model 168 limitations (no-interannual variability in the anthropogenic emissions, errors in the transport, coarse spatial and vertical resolution of the model and overestimation of ozone production efficiency). In particular, the fact that the MOZART-4 model settings used constant 171 anthropogenic emissions tends to strengthen the ability of IASI to detect anthropogenic 172 production of $\mathrm{O}_{3}$ and to highlight the need for developing long term continuous anthropogenic 173 emissions inventories (including seasonal and inter-annual variations) for better estimating the 174 impact of anthropogenic pollution changes on tropospheric ozone levels.

175 2- Our results suggest that even if a large part of the IASI $\mathrm{O}_{3}$ MLT measurements in the N.H. 176 originates from the troposphere (40-60\%), the apparent negative trend in the troposphere 177 observed by IASI in the N.H. summer (see Tables 2 and 3 in Section 4.3.2 of the manuscript) is 178 partly masked by the influence of the stratosphere and of the medium vertical sensitivity of IASI. 179 In other words, the decrease of tropospheric $\mathrm{O}_{3}$, which could be attributed to decline of $\mathrm{O}_{3}$ 180 precursor emissions, is likely attenuated by the positive changes in $\mathrm{O}_{3}$ variations detected in 
181 upper layers. This would mean that the negative trend deduced from IASI could in reality be 182 more important. This opens perspectives to further comprehensive studies for investigating the 183 influence of stratospheric $\mathrm{O}_{3}$ recovery on the apparent decrease of $\mathrm{O}_{3}$ in the troposphere.

184

185

186

187

188

189

190

191

192

193

194

195

196

197

198

199

200

201

202

203

204

205

206

207

208

209

210 


\section{References}

Duflot, V., C. Wespes, L. Clarisse, D. Hurtmans, Y. Ngadi, N. Jones, C. Paton-Walsh, J. HadjiLazaro, C. Vigouroux, M. De Mazière, J.-M. Metzger, E. Mahieu, C. Servais, F. Hase, M. Schneider, C. Clerbaux and P.-F. Coheur: Acetylene (C2H2) and hydrogen cyanide (HCN) from IASI satellite observations: global distributions, validation, and comparison with model, Atmos. Chem. Phys., 15, 10509-10527, doi:10.5194/acp-15-10509-2015, 2015.

Emmons, L. K., Walters, S., Hess, P. G., Lamarque, J.-F., Pfister, G. G., Fillmore, D., Granier, C., Guenther, A., Kinnison, D., Laepple, T., Orlando, J., Tie, X., Tyndall, G., Wiedinmyer, C., Baughcum, S. L., and Kloster, S.: Description and evaluation of the Model for Ozone and Related Chemical Tracers, version 4 (MOZART-4), Geosci. Model Dev., 3, 43-67, 2010a.

Emmons, L.K., Apel, E.C., Lamarque, J.-F., Hess, P. G., Avery, M., Blake, D., Brune, W., Campos, T., Crawford, J., DeCarlo, P. F., Hall, S., Heikes, B., Holloway, J., Jimenez, J. L., Knapp, D. J., Kok, G., Mena-Carrasco, M., Olson, J., O’Sullivan, D., Sachse, G., Walega, J., Weibring, P., Weinheimer, A., and Wiedinmyer, C.: Impact of Mexico City emissions on regional air quality from MOZART-4 simulations, Atmos. Chem. Phys., 10, 6195-6212, doi:10.5194/acp-10-6195-2010, $2010 \mathrm{~b}$.

Emmons, L. K., P.G. Hess, J.-F. Lamarque, and G. G. Pfister: Tagged ozone mechanism for MOZART-4, CAM-chem and other chemical transport models, Geosci. Model Dev., 5, 15311542, doi:10.5194/gmd-5-1531-2012, 2012.

Emmons, L. K., S. R. Arnold, S. A. Monks, V. Huijnen, S. Tilmes, K. S. Law, J. L. Thomas, J.C. Raut, I. Bouarar, S. Turquety, Y. Long, B. Duncan, S. Steenrod, S. Strode, J. Flemming, J. Mao, J. Langner, A. M. Thompson, D. Tarasick, E. C. Apel, D. R. Blake, R. C. Cohen, J. Dibb, G. S. Diskin, A. Fried, S. R. Hall, L. G. Huey, A. J. Weinheimer, A. Wisthaler, T. Mikoviny, J. Nowak, J. Peischl, J. M. Roberts, T. Ryerson, C. Warneke, and D. Helmig: The POLARCAT Model Intercomparison Project (POLMIP):overview and evaluation with observations, Atmos. Chem. Phys., 15, 6721-6744, 2015.

Granier, C., Lamarque, J., Mieville, A., Müller, J., Olivier, J., Orlando, J., Peters, J., Petron, G., Tyndall, G., and Wallens, S.: POET, a database of surface emissions of ozone precursors, available at: http://www.pole-ether.fr/eccad (last access: 22 September 2015), 2005. 
Guenther, A., Karl, T., Harley, P., Wiedinmyer, C., Palmer, P. I., and Geron, C.: Estimates of global terrestrial isoprene emissions using MEGAN (Model of Emissions of Gases and Aerosols from Nature), Atmos. Chem. Phys., 6, 3181-3210, doi: 10.5194/acp-6-3181-2006, 2006.

Horowitz, L., Walters, S., and Mauzerall, D.S.: A global simulation of tropospheric ozone and related tracers: Description and evaluation of MOZART, version 2, J. Geophys. Res., 108, 4784, doi:10.1029/2002JD002853, 2003.

Pfister, G. G., Emmons, L. K., Hess, P. G., Honrath, R., Lamarque, J.-F., Val Martin, M., Owen, R. C., Avery, M. A., Browell, E. V., Holloway, J. S., Nedelec, P., Purvis, R., Ryerson, T. B., Sachse, G. W., and Schlager, H.: Ozone production from the 2004 North American boreal fires, J. Geophys. Res., 111, D24S07, doi:10.1029/2006JD007695, 2006.

Pfister, G. G., Emmons, L. K., Hess, P. G., Lamarque, J.-F., Thompson, A. M., and Yorks, J. E.: Analysis of the summer 2004 ozone budget over the United States using Intercontinental Transport Experiment Ozonesonde Network Study (IONS) observations and Model of Ozone and Related Tracers (MOZART-4) simulations, J. Geophys. Res., 113, D23306, doi:10.1029/2008JD010190, 2008.

Wespes, C., L. Emmons, D. P. Edwards, J. Hannigan, D. Hurtmans, M. Saunois, P.-F. Coheur, C. Clerbaux, M. T. Coffey, R. L. Batchelor, R. Lindenmaier, K. Strong, A. J. Weinheimer, J. B. Nowak, T. B. Ryerson, J. D. Crounse, and P. O. Wennberg: Analysis of ozone and nitric acid in spring and summer arctic pollution using aircraft, ground-based, satellite observations and mozart-4 model: source attribution and partitioning, Atmos. Chem. Phys., 12, 237-259, 2012.

Wiedinmyer, C., Akagi, S. K., Yokelson, R. J., Emmons, L. K., Al-Saadi, J. A., Orlando, J. J., and Soja, A. J.: The Fire INventory from NCAR (FINN) - a high resolution global model to estimate the emissions from open burning, Geosci. Model Dev., 3, 2439-2476, doi:10.5194/gmd3-2439-2010, 2011. 
Table S1 List of the proxies retained in the stepwise backward elimination approach which are

271 significant at the 95\% level (see text for details) for each 20-degree latitude bands and for each

272 partial column. Proxies are indicated for Solar flux (blue), QBO10 (green), QBO30 (orange),

273 ENSO (red) and NAO (pink)/AAO (purple). Symbols indicated between parentheses refer to

274 proxies which are not significant statistically when accounting for the autocorrelation in the 275 noise residuals.

\begin{tabular}{|c|c|c|c|c|c|}
\hline Proxies & $\begin{array}{c}\text { Ground-300hPa } \\
\text { (Troposphere) }\end{array}$ & $\begin{array}{c}\text { 300-150hPa } \\
\text { (UTLS) }\end{array}$ & $\begin{array}{c}\text { 150-25hPa } \\
\text { (MLST) }\end{array}$ & $\begin{array}{c}25-3 \mathrm{hPa} \\
\text { (UST) }\end{array}$ & Total columns \\
\hline $7^{\circ} \mathrm{N}-90^{\circ} \mathrm{N}$ & $(\mathrm{O})(\mathrm{O}) \mathrm{O} \mathrm{O}$ & $\begin{array}{ll}\mathrm{O}(\mathrm{O}) \mathrm{O} & (\mathrm{O})\end{array}$ & $\mathbf{O}(\mathbf{O})(\mathrm{O}) \mathbf{O} \mathrm{O}$ & $(\mathrm{O}) \mathrm{O}(\mathrm{O}) \mathrm{O}$ & $\mathrm{O}(\mathrm{O}) \mathrm{OOO}$ \\
\hline $50^{\circ} \mathrm{N}-\mathbf{7 0}^{\circ} \mathrm{N}$ & $\mathbf{O}(\mathbf{O})(\mathbf{O}) \mathbf{O}(\mathbf{O})$ & O O (O) O & $\mathrm{O}(\mathrm{O})(\mathrm{O}) \mathrm{O} \mathrm{O}$ & $(\mathbf{O})(\mathrm{O})$ & $\mathbf{O}(\mathrm{O})(\mathrm{O}) \mathbf{O} \mathrm{O}$ \\
\hline $30^{\circ} \mathrm{N}-50^{\circ} \mathrm{N}$ & $(\mathbf{O})(\mathrm{O})(\mathrm{O}) \mathrm{O}$ & $\mathbf{O}(\mathbf{O})(\mathbf{O}) \mathbf{O}$ & $\mathbf{O}(\mathbf{O}) \quad \mathbf{O} \quad \mathbf{O}(\mathbf{O})$ & $\mathrm{O}(\mathrm{O})(\mathrm{O})(\mathrm{O})$ & $\mathbf{O}(\mathrm{O})(\mathrm{O}) \mathbf{O} \mathrm{O}$ \\
\hline $10^{\circ} \mathrm{N}-30^{\circ} \mathrm{N}$ & $(\mathbf{O})(\mathbf{O}) \quad(\mathbf{O})$ & $(\mathrm{O}) \mathrm{O}(\mathrm{O}) \mathrm{O}(\mathrm{O})$ & $(\mathbf{O})(\mathrm{O})(\mathrm{O}) \mathbf{O} \mathrm{O}$ & $\mathrm{O}(\mathrm{O})(\mathrm{O})$ & $\mathrm{O}(\mathrm{O}) \mathrm{O} \mathrm{O}$ \\
\hline $10^{\circ} S-10^{\circ} N$ & $(\mathbf{O}) \mathrm{O}(\mathrm{O})(\mathrm{O})(\mathrm{O})$ & OOOOO & $(0) \mathrm{OO}(\mathrm{O})(\mathrm{O})$ & O O & $(\mathrm{O}) \mathrm{O} O \mathrm{O}(\mathrm{O})(\mathrm{O})$ \\
\hline $30^{\circ} S-10^{\circ} S$ & $(\mathbf{O})(\mathrm{O})(\mathrm{O}) \quad(\mathrm{O})$ & $(\mathbf{O}) \mathrm{O}(\mathrm{O}) \mathrm{O}(\mathrm{O})$ & $\mathbf{O}(\mathbf{O}) \mathbf{O} \mathbf{O} \quad(\mathbf{O})$ & $(0) 000 \quad(0)$ & $(\mathrm{O})(\mathrm{O}) \mathrm{O} O$ \\
\hline $\mathbf{5 0}^{\circ} \mathbf{S}-\mathbf{3 0}{ }^{\circ} \mathbf{S}$ & $(\mathrm{O})(\mathrm{O})(\mathrm{O}) \mathrm{O}(\mathrm{O})$ & $(\mathrm{O}) \mathrm{O}(\mathrm{O}) \mathrm{O} \quad \mathrm{O}$ & $\begin{array}{llllll}0 & 0 & 0 & (0)\end{array}$ & $(0) 000 \quad(0)$ & $(\mathrm{O})(\mathrm{O}) \mathrm{O} O \quad(\mathrm{O})$ \\
\hline $\mathbf{7 0}^{\circ} \mathbf{S}-\mathbf{5 0}{ }^{\circ} \mathrm{S}$ & $\mathbf{O}(\mathbf{O})(\mathbf{O})$ & $(\mathbf{O}) \mathrm{O}(\mathrm{O}) \quad \mathrm{O}$ & $(\mathbf{O})(\mathrm{O}) \mathrm{O}(\mathrm{O}) \mathrm{O}$ & $(0) 00 \quad(0)$ & (O) (O) 0 O O \\
\hline $90^{\circ} \mathbf{S}-\mathbf{7 0}^{\circ} \mathrm{S}$ & (O) $0 \quad 0$ & (O) $\mathrm{O}(\mathrm{O}) \mathrm{O}$ & $(\mathrm{O})(\mathrm{O})(\mathrm{O})(\mathrm{O})(\mathrm{O})$ & $\mathbf{O}(\mathbf{O})$ & $(\mathbf{O})(\mathrm{O})(\mathrm{O})(\mathrm{O})(\mathrm{O})$ \\
\hline
\end{tabular}

276

277

278

279

280

281

282

283

284

285

286

287

288

289 
(a)
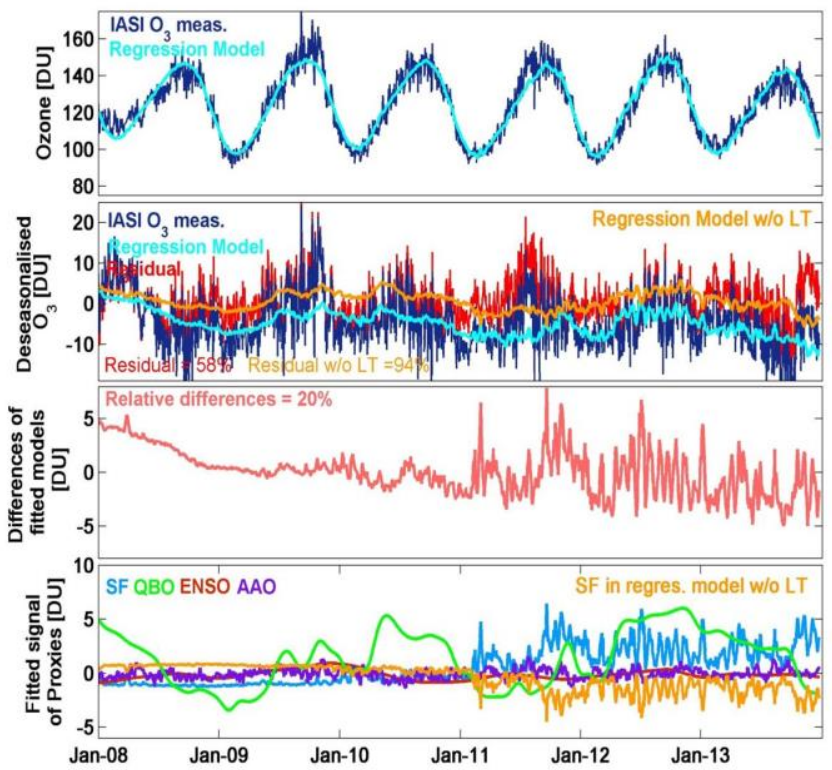

(b)

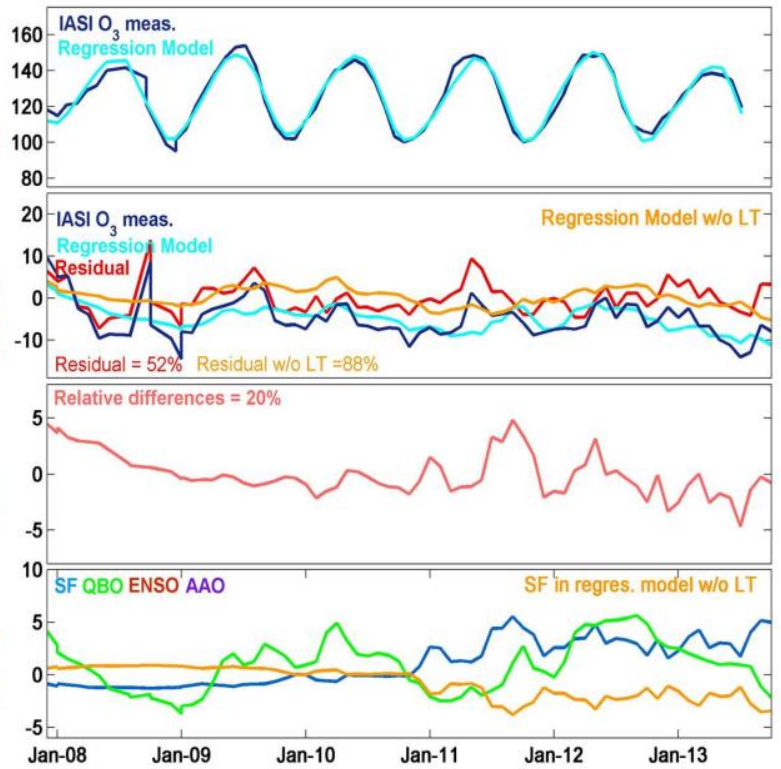

Figure S1: Same as Figure 9 of the manuscript, but in the UST for the $30^{\circ} \mathrm{S}-50^{\circ} \mathrm{S}$ latitude band. 

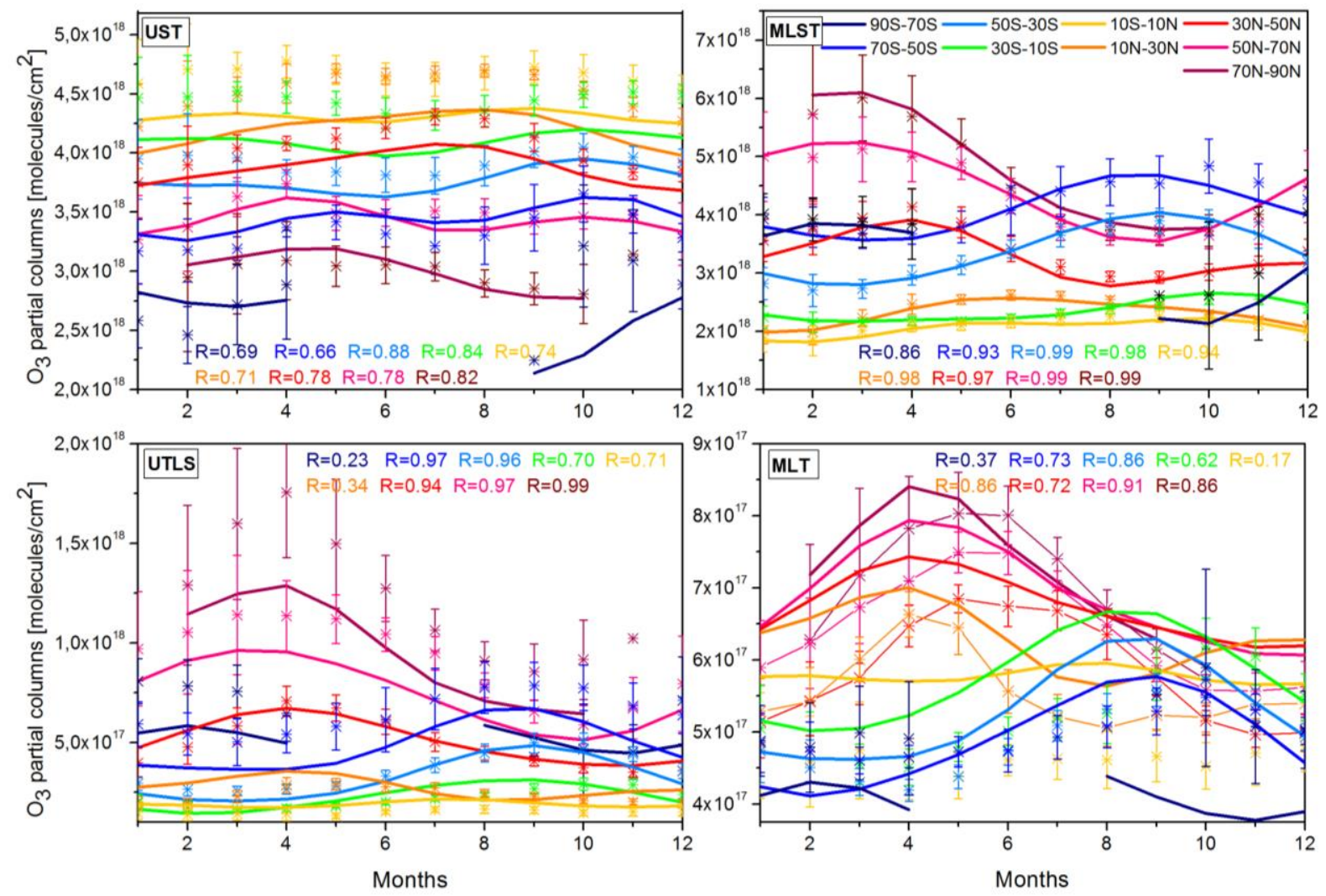

Figure S2: Same as Figure 7 of the manuscript, but for the fit of MOZART-4 simulations (line)

298 smoothed according to the averaging kernels of the IASI observations. The IASI $\mathrm{O}_{3}$ columns

299 observations (stars) are indicated for the sake of comparison. In the N.H. for the MLT, they are

300 plotted with lines and symbols for clarity. Correlation coefficients (R) between the daily median

301 fitting of IASI and of the smoothed MOZART-4 are also indicated. Note that the scales are 302 different. 


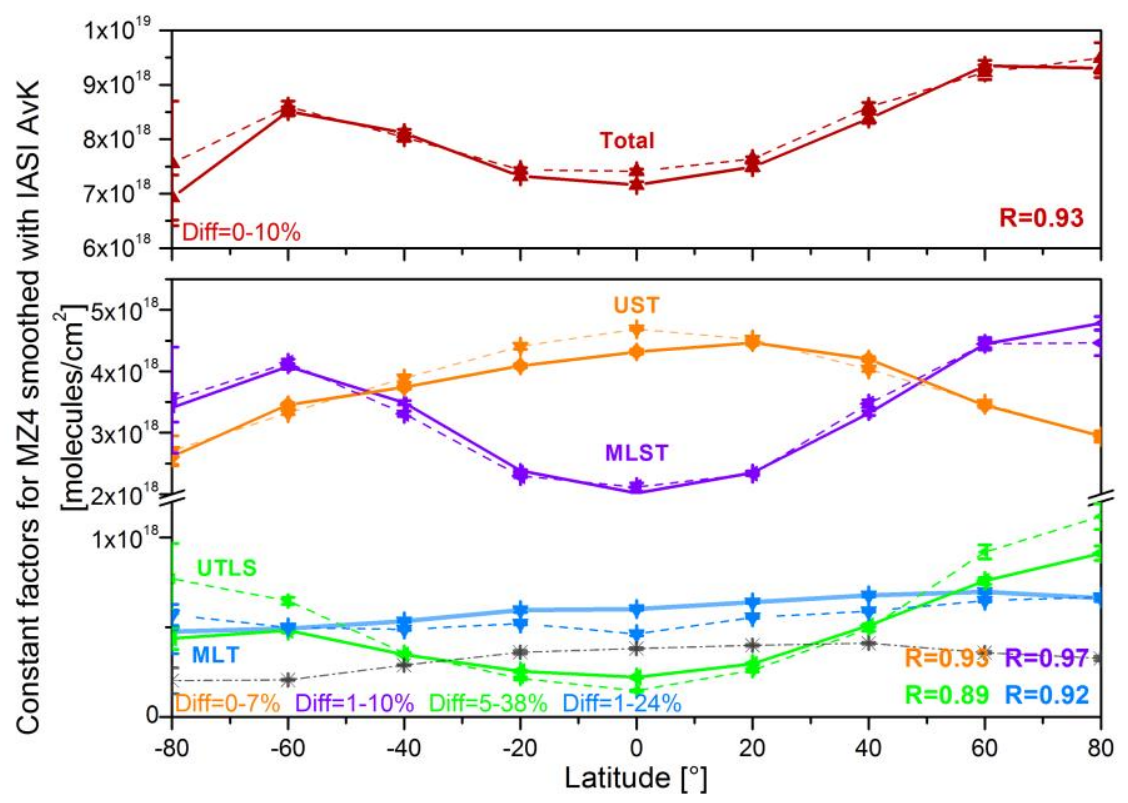

305

Figure S3. Same as Fig.8 (a) of the manuscript but for the MOZART-4 $\mathrm{O}_{3}$ time series, smoothed according to the averaging kernels of IASI. Correlation coefficient (R) and relative differences between the Constant factors in the IASI fitting time series (dashed line) and in the MOZART-4 fitting time series (full line) are also indicated. For the troposphere, the Constant factors in the MOZART- $4 \mathrm{O}_{3}{ }^{\text {tagged_NOx }}$ fitting time series are also represented (dashed grey). 
(a)

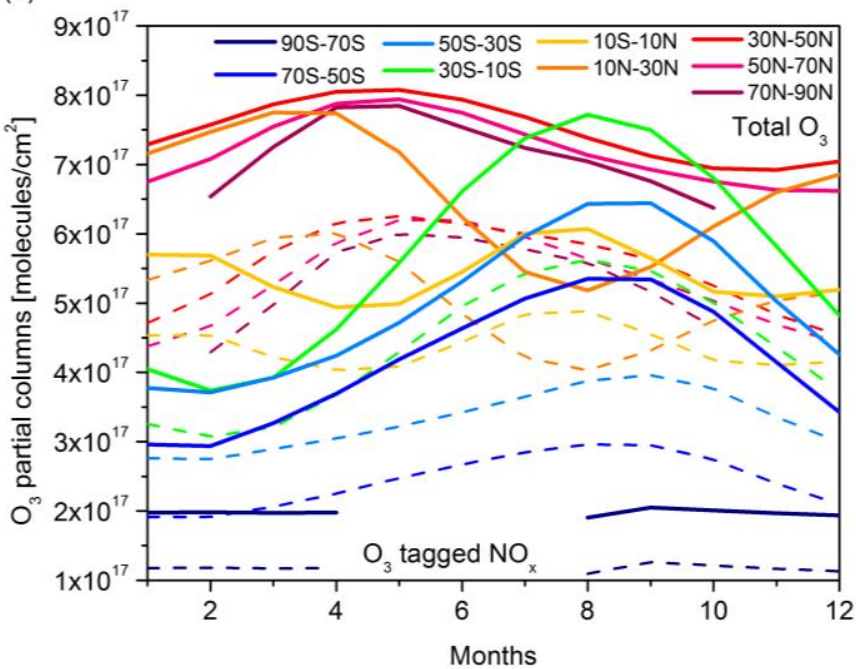

(b)

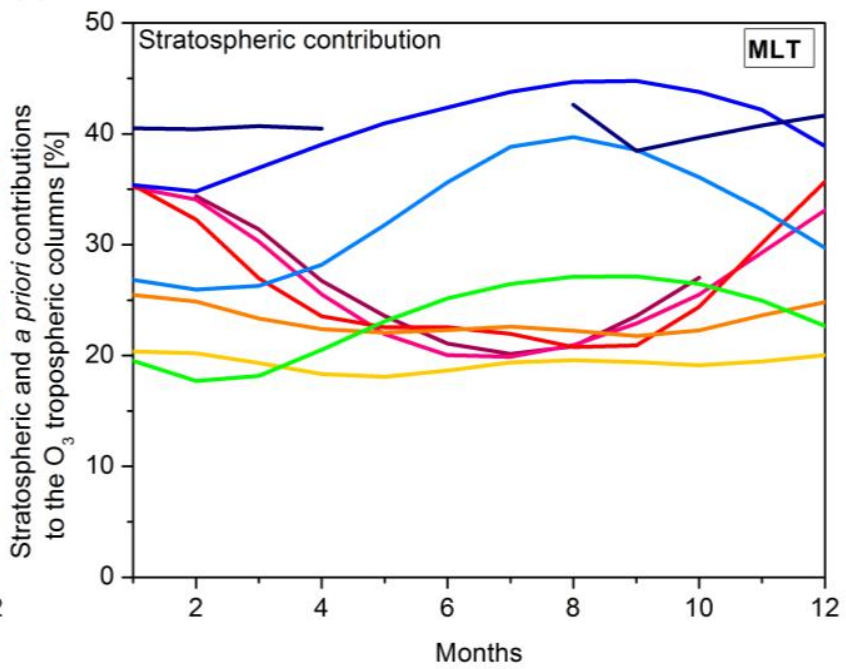

(a)

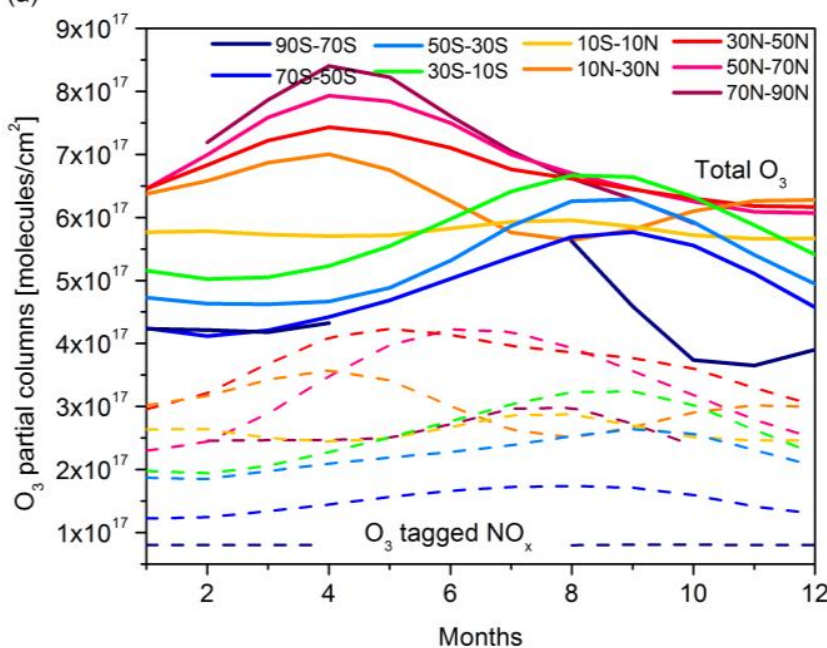

(b)

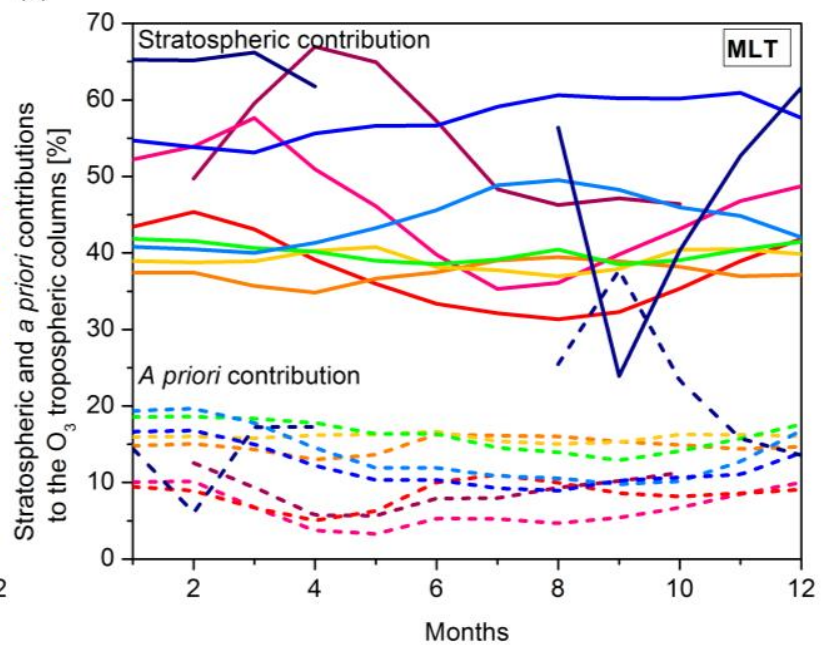

322 Figure S5: (a) Same as Figure S4 but accounting for the IASI sensitivity. (b) Contribution to the 323 MLT columns (\%) from the stratosphere simulated by MOZART-4 accounting for the IASI 324 sensitivity (full line) and from the a priori information (dashed line). 
(a)

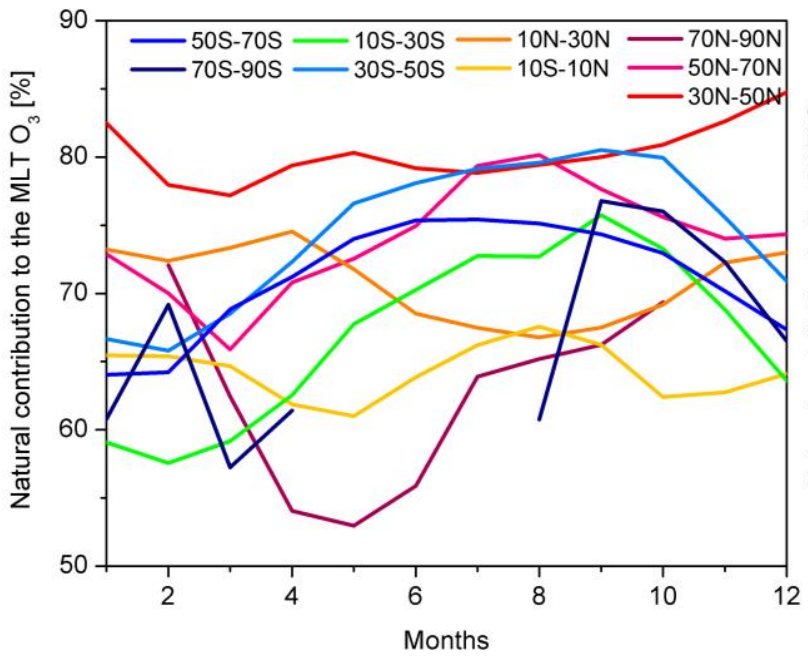

325

326

327 328 (b)

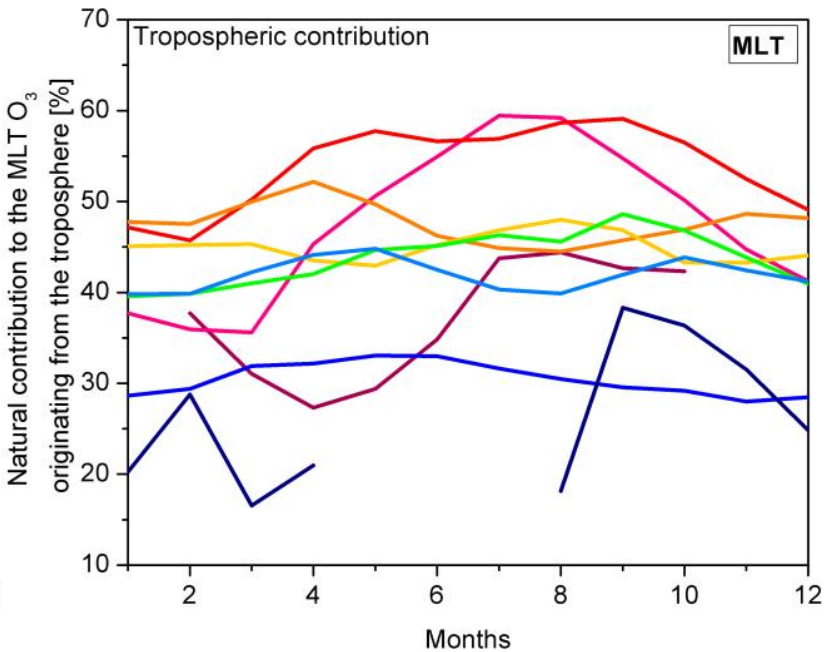

Figure S6: Contribution to the IASI MLT $\mathrm{O}_{3}$ columns (\%) (a) of the natural variability (troposphere and stratosphere) and (b) from the troposphere. 